\title{
THE PARENTAL RESPONSIBILITY CONCEPT IN REPLACING CRIMINAL RESPONSIBILITY OF CHILD TO PARENT (THE STUDY OF INDONESIAN TRIBES CULTURE IN LAMPUNG AND AGA BALINESE TRIBES )
}

\author{
Umi Rozah \\ Faculty of Law, University Diponegoro \\ umi_rozah@yahoo.com
}

\begin{abstract}
Crime is some action which declared that it should not be done by anyone, no matters adults, juveniles or child. Anyone should be punished if he/she has done any crime which harmed or injuried someone or violated social order, as that was formulated in an Act and threated by punishment. An interesting question here are : How is the roles of parents in liability for any crimes which done by her/his child? Why the parents should endure liabilities for any crime that he/she did not do it but just for child that may be they know nothing about that.

This written based on research which is performed in Lampung Tribe Society and Balinese Tribe Society. Law is a mirror of society become an entry poin to access and to understand how cultures both of Lampung and Balinese Tribes Society to solve any crime that was done by the child. Here, the author wrote based on the penal codes Cepalo Walu Ngepuluh which is prevailing in Lampung Tribes Culture and Kitab Manawa Dharmacastra which is applying at Balinese Tribes Culture.

This method research was performed by sociol legal research approach, that mixed socio research approach to search values of both tribes society behavior in resolve the matters or crimes which was done by juveniles in the one hand, and in the other hand this research used libraries approach to search any documents or any literatures that be related with how to resolve any crime was done by a juvenile.

This article is very interesting because in Indonesian Penal Codes did not impose parental responsibility for the child's offence. So this article could be the way out to relocating the child's criminal responsibility to his/her parents.
\end{abstract}

Keywords : Parental Responsibility, Child, Parents

\section{Introduction}

The Juveniles in crime in Indonesian criminal justice system has been regulated on The Juveniles Criminal Justice System Act Number 11, 2012 . Article 1 Number 2 The Juveniles Criminal Justice System Act Number 11, 2012 states that "The Juveniles involved within the law is the juveniles who have any conflict in the law, so they have to face the criminal justice system. Juveniles age in this regulation is 12 years old but not 18 years old yet who were accused have done any offence". According to this regulation the child who allows get into criminal justice process in that age limits could be responsibled for any offence that she /he had done. On the name the best interest for the child who was involved in the criminal justice process, there was a diversion that had been regulated by The Juveniles Criminal Justice System Act Number 11, 2012. 
Meanwhile, the juveniles who were not given diversion, she/he have to responsible to her/his offence. The judge could impose punishment to juveniles such as imprisonment, fine, community social order or verbal sentence. So no one could replace his/her responsibility. In this case criminal law applied individual responsibility.

A problem which rises is how about the child under 12 years who did any offence ? will they get in criminal justice process, and get a punishment? How the parents take a role for responsibility of their child's offences if they are under 12 years. Meanwhile no one could be responsibled to the offence which had done by the child under 12 years, but there were harms or injuries and victims. The child in this written means the child who is under 12 years doing an offence but can not be processed in criminal law justice system cause of absence in criminal responsibility.

There is a case which had done by the child under 12 years, such as a case of murder that had done by DM, a child 9 years and the judges of The District Court of Manokwari stated that he was guilty in murder to his friend AAR, but not imposing any punishment to him. In this case the judges released the offender from any punishment cause of his age, but only asked him to pay the cost of justice process amount Rp. 1000. Then judges established to bring the child offender back to his parent (Surat Dari Poltangan, Manokwari.com., 14 October,2011). In this case, no one could be taken responsibility to the harm of victim who was taken his life by the child offender. How about the victim's family who had losen his/her child's life? In this case needs any way to take responsibility of the parent to replace his/her child's liability in crime, which is known as parental responsibility in criminal matters.

In criminal law context parental responsibility is the responsibility of parent for the offence which had done by his/her child. Here, parent take handling of all harms or injures which is caused that offence. Indonesian criminal law had not regulated about parental responsibility in criminal matters, so it was an interesting stuff to discuss.

\section{Method and Materials}

This article based on research result which had performed in the Aga Balinese Tribes Culture in Bali and the Lampung Tribes Culture in Lampung. Sociolegal research approach with hermenuetics philosophy had used in this research. Sociolegal approach is an alternative approach which examines doctrinal study to the law, that represents relation between the context where is the law lies (an interface with context within which law exists). Meanwhile, 
hermeneutics philosophy in this sociolegal research was used to inquiry principle of responsibility that sourced of the living law values and the ever living law values in Lampung dan Aga Balinese cultures. Its sourced of the written Penal Code or unwritten law .

This research also used constructivism paradigm or interpretive paradigm, to understand the relatively truth of reality, that prevailed in accordance with the specific context which is relevant with social actors. This constructivism research paradigm had been used to search perceptions of research subjects on customs of applying parental responsibility for the child's offence based on people's experiences on social life, religion, culture and values system of the subject.

\section{Result and Discussion}

\subsection{The Concept of Criminal Responsibilty}

The characteristic of our own and all advanced legal systems that the individual's liability to punishment, at any rate for serious crimes carrying severe penalties, is made by law to depend among other things, on certain mental condition. These condition can best be expressed in negative form as excusing conditions: the individual is not liable to punishment if at the same time of his doing what would otherwise be a punishable act he was unconscious, mistaken about the physical consequences of his bodily movements or the nature or qualities of the thing or persons affected by them, or, in some or was the victim of certain types of mental disease. ${ }^{1}$

In Anglo American criminal law this is the doctrine that a subjective or mens rea is required for criminal responsibility, and it is because of this doctrine that criminal trial may involve investigation into the sanity of the accused. Here, there are two ways in applying criminal responsibility. First, our law admits crimes of strict liability. These are crimes where it is no defence to show that the accused, in spite of the exercise of proper care, was ignorant of the facts that made his act illegal. Here he is liable to punishment even though he did not intend to commit an act answering definition of the crime.Secondly, even in regard to crime where liability is not strict, so that mistake or accident rendering the accused's action unintentional would provide an excuse ( H.L.A Hart,2009,p.28).

The core of principle of criminal responsibilty is individual's responsibility, so only the offender own self who was liable for his /her crimes. But in certain case strict liability could be 
applied. In other doctrin state that strict liability could be defined as liability without fault or blameworthiness, it derives vicarious liability which applied liability for the acts or omissions of another.

The definition of vicarious liability is a legal doctrine that assigns liability for an injury to a person who did not cause the injury but who has a particular legal relationship to a person who did act negligently. It is also referred to as imputed negligence. Legal relationships that can lead to include the relationship between parent and child, husband and wife, owner of a vihacle and driver, employer and employee. (The Legal Dictionary, The Free Dictionary.com).

\subsection{The Parental Responsibilty Concept Based On Indonesian Culture}

The parental responsibility is a part of responsibility of parent to his/her child's conduct which rises harms or injuries or victim. Generally, parental responsibility is defined as being all the "right, duties, powers, responsibilities and authority which by law a parent of a child has in relation to the child and his property". In practical parental responsibility means the power to make important decisions in relation to a child, this can include : determining the religion the child should be brought up with until the child can reach an age where he/she can make their own decision on this; Determining the child's education and where the child goes to school; Choosing, registering or changing the child's name; Appointing a child's guardian in the event of death of a parent; Consenting to a child's operation or certain medical treatment; Accessing a child's medical records; Consenting to taking the child abroad for holidays or extended stays; and representing the child in legal proceedings. (S. 3(1) Children Act 1989, Childlawadvice. Org.uk)

Indonesian culture, especially Aga Balinese Tribes Culture and Lampung Tribes Culture had applied criminal parental responsibility to replace child's responsibility for any conducts which caused harms or injuries of victim. The shape of parental responsibility here such as fine and restitution for victim who had gotten any injuries or harms. The parent of the child who had committed an offence should pay fine to the society and at once to pay restitution to restore harm or injuries.

Written in Cepalo Walu Ngepuluh of Lampung Tribes Penal Code Article 20 said that if a fighting between children under 14 years old caused injuries, so then this conduct regarded commited by father or mother of the child. And then they should to resposible to slaughtering a buffalo or a sheep to take any cermony" (Ki pida sanak lunik di behan umur pak belas tahun pisuw pido sanak. Ki yo silat, busuk, mako dibeasoken indui/apak sanak si ngatani/mussuki sino" \# Lampung Tribes Languange).Replacing criminal responsibility of the child's conducts to 
his/her parent under age based on the kinship concept that established the parent should responsible to educating, guideling, and controling their children, in order to the children avoided from prohabited conducts and conformed to the norms in their society. In the case the offender under 14 years old, so criminal responsibility got in the parent's burden.

Philosophy reasonings parental responsibility in Indonesian culture as follow :

a. Its duties of parent to educating, leading,and controling his/her child's behavior to conform to the norms in society, in order to be avoided to commit any prohibited conducts.

b. The offence which is committed by the child as one of shape failures of parent in his/her duty and obligation to educating, leading, dan controling of his/her child's behavior, and therefore he/she should take any burden to responsible for his/her child's offence as relocating or replacing criminal responsibility of his/her child's criminal responsibility.

c. There are many countries that had applied concept of criminal parental responsibility as a replacing of criminal resposibility of the child under 12 years to his/her parent. (Umi Rozah,2015,p. 647)

As a comparative study on parental criminal responsibility in many countries, the author present of them as follows : 1). Washington, Witten on R.C.W.A 4.24. 190, Liability imposed on parents when child willfully or maliciously injuries person or destroys property, and should pay fine amount \$. 5.000 for Minor (Under 18 age) ; 2). California, written on Code 1714.1 (willful misconduct)Code 17.14.3 (Discharge of firearms) Code 17707 (Liability for Minor's Driving) said that a). Parents jointly and severally liable for willful misconduct causing injury, death or property damage, should pay fine amount $\$ .25 .000 ; \mathrm{b}$ ). Parents liable if permitted child to have firearm or left it someplace accessible, and should pay fine amount\$.25.000; c).Person verifying minor's licence applicstion liable for driving of minor.d). Parents jointly or severally liable for negligent driving of child, for two conducts parent should pay fine amount \$.30.000/60.000 for Minor (under 18). 3) Delaware, written on 21 Del 6104-6105 and 10 Del 3922, established that : a). Parents, guardiang or employer who signed license application liable for damages caused by minor driver. b). Owner of vehicle liable for damages caused by minor given permission to operate vehicle. c). Parents liable for intentional or reckless damage to real or personal property. They should pay fine amount $\$ 5000$. 


\section{Conclusion}

Basically, criminal responsibility is individual responsibility for any prohibited conducts and threated by punishment that had done by someone. However, in the cases that offences was done by a child under age who was not regulated in Juveniles Criminal Justice System Act Number 11, 2012, cause of his/her under 12 years old, so there was lack of responsibility. But his/her offences arised any damages or harms or injuries and a victim. This case need someone to handle her/his responsibility to fulfill or restore any damages or harms or injuries that was occured by a victim.

It was needed in criminal justice system to relocate or replace criminal responsibility from the child under age to his/her parent for an offence that he/she had done cause of absence from his/her responsibility, namely is parental responsibility as prevailed in Indonesian Tribes Cultures.

\section{References}

Andrew Ashworth, 2005, Sentencing and Criminal Justice, 4th Edition, New York : Cambridge University Press.

Anthony Duff and David Garland, 1995, A Reader On Punishment, Oxford : Oxford University Press.

Andrew Von Hirsch, 1993, Censure and Sanctions, Oxford New York : Oxford University Press.

Barbara A. Hudson, 1996, Understanding Justice An introduction to Ideas, Perspectives and Controversies in Modern Penal Theory, Philadelphia : Open University Press.

Burton Wright and Vernon Fox, 1978, Criminal Justice and the Social Sciences, Philadelphia London Toronto, W.B. Saunders Company.

H.L.A Hart,2009, Punishment and Responsibility Essay s in the Philosophy of Law, Second Edition, New York, Oxford University Press.

Umi Rozah, Membangun Asas Pemidanaan Dalam Kerangka Pancasila ( Disertasi), Semarang, Program Doktoral Ilmu Hukum Fakultas Hukum Undip.

The Legal Dictionary, The Free Dictionary.com. 
The Parental Responsibility Concept in Replacing Criminal Responsibility of Child to Parent (The Study of Indonesian Tribes Culture in Lampung and Aga Balinese Tribes )

S. 3(1) Children Act 1989, Childlawadvice. Org.uk.

Surat Dari Poltangan, Manokwari.com., 14 October,2011. 